\title{
Correction to: Effects of implementing a postabortion care strategy in Kinshasa referral hospitals, Democratic Republic of the Congo
}

\author{
Daniel Katuashi Ishoso ${ }^{1 *} \mathbb{D}$, Antoinette Tshefu' ${ }^{1}$ Thérèse Delvaux², Michèle Dramaix ${ }^{3}$, Guy Mukumpuri ${ }^{4}$ and \\ Yves Coppieters ${ }^{5}$
}

\section{Correction to: Reprod Health (2021) 18:76 https://doi.org/10.1186/s12978-021-01130-x}

Following publication of the original article [1] two errors have been identified in the abstract and the plain English summary.

The incorrect and correct information is listed below; the changes are shown in bold.

\section{Incorrect}

Abstract

The implementation of PAC strategy in Kinshasa referral hospitals has resulted in the utilization of WHO recommended uterine evacuation method MVA (29.3\% more in the experimental structures, $p=0.025)$, a significant decline in sharp-curettage $(19.3 \%$ less, $\mathrm{p}=0.132)$, and a decline in the duration of hospitalization of patients admitted for PAC ( 1 day less, $p=0.020$ ).

Plain English summary

The implementation of PAC strategy in Kinshasa referral hospitals has resulted in the utilization of WHO recommended uterine evacuation method MVA $(29.3 \%$ more in the experimental structures, $\mathrm{p}=0.025)$, a significant decline in sharp-curettage $(19.3 \%$ less, $\mathrm{p}=0.132$ ), and a decline in the duration of hospitalization of patients admitted for PAC ( 1 day less, $\mathrm{p}=0.020$ ).

\section{Correct}

Abstract

The implementation of PAC strategy in Kinshasa referral hospitals has resulted in the utilization of WHO recommended uterine evacuation method MVA (29.3\% more in the experimental structures, $\mathrm{p}=0.025)$, a nonsignificant decline in sharp-curettage $(19.3 \%$ less, $\mathrm{p}=0.132)$, and a decline in the duration of hospitalization of patients admitted for PAC ( 1 day less, $\mathrm{p}=0.020)$.

Plain English summary

The implementation of PAC strategy in Kinshasa referral hospitals has resulted in the utilization of WHO recommended uterine evacuation method MVA (29.3\% more in the experimental structures, $\mathrm{p}=0.025)$, a nonsignificant decline in sharp-curettage $(19.3 \%$ less, $\mathrm{p}=0.132)$, and a decline in the duration of hospitalization of patients admitted for PAC ( 1 day less, $\mathrm{p}=0.020)$.

\footnotetext{
*Correspondence: dishosok@gmail.com

${ }^{1}$ Community Health Department, Kinshasa School of Public Health,

University of Kinshasa, PO Box11850, Kinshasa1, Democratic Republic of Congo

Full list of author information is available at the end of the article
}

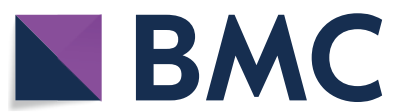

(c) The Author(s) 2021. This article is licensed under a Creative Commons Attribution 4.0 International License, which permits use, sharing, adaptation, distribution and reproduction in any medium or format, as long as you give appropriate credit to the original author(s) and the source, provide a link to the Creative Commons licence, and indicate if changes were made. The images or other third party material in this article are included in the article's Creative Commons licence, unless indicated otherwise in a credit line to the material. If material is not included in the article's Creative Commons licence and your intended use is not permitted by statutory regulation or exceeds the permitted use, you will need to obtain permission directly from the copyright holder. To view a copy of this licence, visit http://creativecommons.org/licenses/by/4.0/. The Creative Commons Public Domain Dedication waiver (http://creativecommons.org/publicdomain/zero/1.0/) applies to the data made available in this article, unless otherwise stated in a credit line to the data. 


\section{Author details}

${ }^{1}$ Community Health Department, Kinshasa School of Public Health, University of Kinshasa, PO Box1 1850, Kinshasa1, Democratic Republic of Congo. ${ }^{2}$ Public Health Department, Institute of Tropical Medicine, ITM, Antwerp, Belgium. ${ }^{3}$ Research Centre of Epidemiology, Biostatistics and Clinical Research, School of Public Health, Université Libre de Bruxelles, Brussels, Belgium. ${ }^{4}$ Safe Motherhood Division, National Reproductive Health Program, Ministry of Public Health, Kinshasa, Democratic Republic of Congo. ${ }^{5}$ Research Centre "Policies and Health Systems-International Health", School of Public Health, Université Libre de Bruxelles (ULB), Brussels, Belgium.

\section{Reference}

1. Ishoso DK, Tshefu A, Delvaux T, Dramaix M, Mukumpuri G, Coppieters Y. Effects of implementing a postabortion care strategy in Kinshasa referral hospitals, Democratic Republic of the Congo. Reprod Health. 2021;18:76. https://doi.org/10.1186/s12978-021-01130-x.

\section{Publisher's Note}

Springer Nature remains neutral with regard to jurisdictional claims in published maps and institutional affiliations.

Published online: 22 July 2021

Ready to submit your research? Choose BMC and benefit from:

- fast, convenient online submission

- thorough peer review by experienced researchers in your field

- rapid publication on acceptance

- support for research data, including large and complex data types

- gold Open Access which fosters wider collaboration and increased citations

- maximum visibility for your research: over $100 \mathrm{M}$ website views per year

At BMC, research is always in progress.

Learn more biomedcentral.com/submissions 